\title{
Repeated bottom-water oxygenation during OAE 2: timing and duration of short-lived benthic foraminiferal repopulation events (Wunstorf, northern Germany)
}

\author{
OLIVER FRIEDRICH*, SILKE VOIGT, TANJA KUHNT \& MIRJAM C. KOCH \\ Institut für Geowissenschaften, Goethe-Universität Frankfurt/Main, Altenhöferallee 1, 60438 Frankfurt/Main, Germany \\ ${ }^{*}$ Corresponding author (e-mail: o.friedrich@em.uni-frankfurt.de)
}

\begin{abstract}
Published proxy data for Oceanic Anoxic Event 2 (OAE 2 or Cenomanian-Turonian Boundary Event) and other mid-Cretaceous OAEs indicate widespread anoxic bottom-water conditions. However, increasing evidence shows that anoxia was not permanent but subject to significant fluctuations. We have generated X-ray fluorescence elemental concentration and benthic foraminiferal assemblage records for a short section of OAE 2 black shales from Wunstorf, northern Germany. Two intervals of low sulphur elemental concentration are interpreted as periods of increased oxygenation of bottom waters. This is supported by benthic foraminiferal assemblage data showing repopulation events associated with these intervals. These repopulation events are characterized mainly by the occurrence of agglutinated taxa, with Lingulogavelinella globosa being the only abundant calcareous species. This observation is interpreted in terms of short-term interruptions of the otherwise anoxic bottom-water environment. Comparison with repopulation events during OAE $1 \mathrm{~b}$ and Quaternary sapropels make it reasonable to speculate that short-term cooling and an associated increase in bottom-water ventilation at the NW European shelf sea are the main trigger mechanisms for the observed repopulation events at Wunstorf. As source area for benthic foraminifera, shallower parts of the Lower Saxony basin are proposed. J. Micropalaeontol. 30(2): 119-128, September 2011.
\end{abstract}

Supplementary material: XRF elemental concentrations and benthic foraminiferal counts, are available at: http://www.geolsoc.org.uk/SUP18496

KEYWORDS: Oceanic Anoxic Event 2, benthic foraminifera, repopulation events, Cenomanian, Turonian

\section{INTRODUCTION}

Oceanic Anoxic Event 2 (OAE 2), stratigraphically situated around the Cenomanian/Turonian boundary, represents the most prominent mid-Cretaceous OAE and is associated with one of the most severe carbon-cycle perturbations of the last 120 Ma (Schlanger \& Jenkyns, 1976; Arthur et al., 1988; Leckie et al., 2002). OAE 2 occurs during the so-called mid-Cretaceous super-greenhouse climate with sea-surface temperatures above $30^{\circ} \mathrm{C}$ (e.g. Huber et al., 2002; Norris et al., 2002; Wilson et al., 2002; Forster et al., 2007; Moriya et al., 2007; Bornemann et al., 2008) and intermediate- to bottom-water temperatures far exceeding today's values (e.g. Huber et al., 2002; Friedrich et al., 2008a). The pronounced positive carbon isotope excursion associated with OAE 2 reflects massive drawdown of organic material into sediments due to enhanced preservation and/or surface-water productivity (e.g. Scholle \& Arthur, 1980; Arthur et al., 1988; Kolonic et al., 2005; Hardas \& Mutterlose, 2007). One of the most characteristic features of OAE 2 is the existence of extremely low oxygen conditions (or even anoxia) in bottom waters (e.g. Pratt \& Threlkeld, 1984; Hasegawa, 1997; Holbourn \& Kuhnt, 2002; Erbacher et al., 2005; Friedrich et al., 2006; Gebhardt et al., 2010) and in the photic zone (Kuypers et al., 2002; Pancost et al., 2004) throughout large parts of the ocean basins. There is, however, increasing evidence that short-term reoxygenation of the seafloor occurred during OAE 2. In the western tropical North Atlantic, Friedrich et al. (2006) showed a significant repopulation event of benthic foraminifera across the Demerara Rise depth transect (Ocean Drilling Program, ODP, Leg 207, off Suriname). The authors tentatively correlated this event with the 'benthonic zone' of OAE 2 successions in the Western Interior Seaway (e.g. Eicher \& Worstell, 1970; Eicher \&
Diner, 1985; Leckie, 1985; Leckie et al., 1998; West et al., 1998; Keller et al., 2004) and a Bolivina-dominated biofacies in the lower third of OAE 2 at Tarfaya, NW Africa (Kuhnt et al., 2005). Cooling of sea-surface temperatures (SST) in the order of several degrees (Forster et al., 2007; Sinninghe Damstè et al., 2010) accompanied this repopulation event. In general, benthic foraminiferal repopulation events are a common feature during mid-Cretaceous OAEs (see discussion in Friedrich, 2010). The best studied of these events occurred during the early Albian OAE $1 \mathrm{~b}$, for which high-resolution benthic foraminiferal data reveal a cyclic pattern of repopulation events on the order of one event every $\sim 5.7 \mathrm{ka}$ (Friedrich et al., 2005). Some of these events have been correlated across the Vocontian Basin (SE France) and within the North Atlantic (Blake Plateau, Erbacher et al., 1999; Holbourn et al., 2001a, b; Mazagan Plateau, Friedrich et al., 2005).

The timing and duration of benthic foraminiferal repopulation events and the response time of benthic foraminifera to reoccupy formerly anoxic environments of OAEs, however, are still poorly constrained. The high-resolution case study for the early Albian OAE $1 \mathrm{~b}$ indicates an estimated duration of $\sim 500$ to 1250 years for single repopulation events (Friedrich et al., 2005), somewhat similar to benthic foraminiferal repopulation events during Quaternary Sapropels S1, S5 and S6 (e.g. Rohling et al., 1997; Casford et al., 2003; Schmiedl et al., 2003; Kuhnt et al., 2007). The dataset of OAE $1 \mathrm{~b}$, however, does not allow a detailed reconstruction of lead and lags between seafloor anoxia and benthic foraminiferal repopulation events.

This study contributes to a better understanding of the environmental change associated with short-term oxygenation events during OAE 2 and to assessment of the response time of 


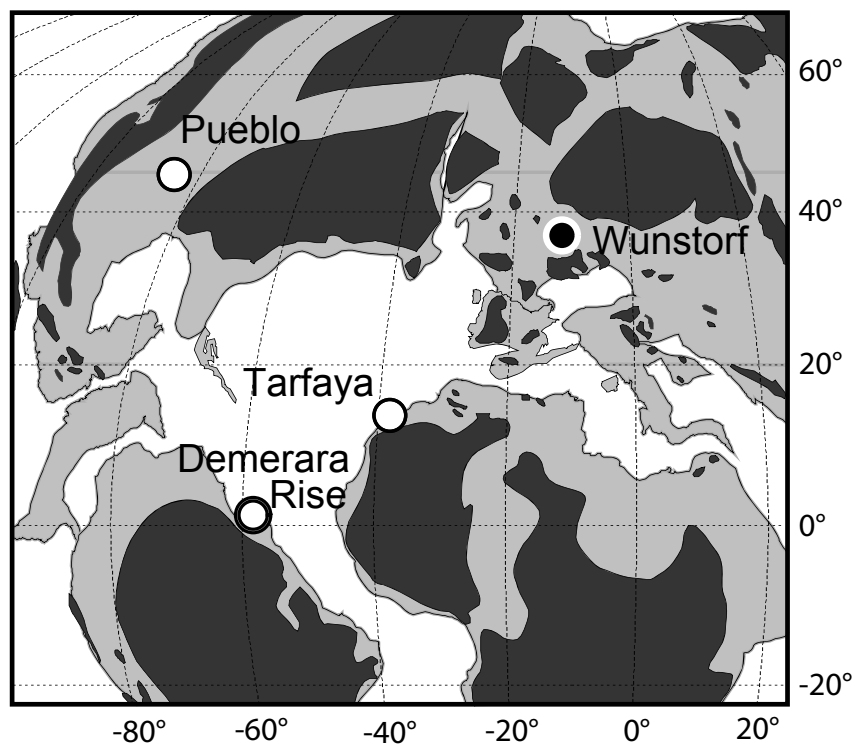

Fig. 1. Palaeoceanographic map of the Cenomanian, with the location of the Wunstorf core and other locations mentioned in the text (modified after Voigt et al., 2008). Continents shown in dark grey, epicontinental seas and shelf areas in light grey, and open ocean in white.

benthic foraminiferal faunas to these events. We present lowerresolution X-ray fluorescence (XRF) elemental concentrations of $\mathrm{S}, \mathrm{Si}$ and $\mathrm{Al}$ (0.7 ka resolution) for the black shale interval from the Wunstorf core (northern Germany) and benthic foraminiferal assemblage data $(0.7$ to $1.7 \mathrm{ka}$ resolution) and high-resolution XRF Si/Al ratio and sulphur elemental concentrations (SEC; 70 years resolution) for the main black shale event (so-called Fischschiefer). Assuming that SEC represents the concentration of pyrite in the sediment, we use it as an indicator of redox conditions and, therefore, oxygenation at the seafloor. Stable carbon isotope data as well as a compelling cyclostratigraphy already exist for this core (Voigt et al., 2008). This allows us to document a lead-lag relationship between bottom-water oxygenation/ventilation and benthic foraminiferal assemblages and to shed new light on short-term palaeoceanographic changes during OAE 2.

\section{GEOLOGICAL SETTING, MATERIALS AND METHODS}

The Wunstorf core, drilled in 2006 northwest of Hannover, is located in the Lower Saxony Basin and represents a sedimentary succession deposited within an intra-shelf basin of the NW European shelf sea (Voigt et al., 2008; Fig. 1). Intra-shelf basins of this domain were spatially confined depocentres (Surlyk et al., 2003) with accumulation of organic-rich, partly laminated mudstones (black shales) during OAE 2. The estimated palaeo-water depth exceeded 100-150 m based on biofacies and sedimentary data in northern Germany (Wilmsen, 2003).

At Wunstorf, the deposition of black shales is orbitally forced by short eccentricity modulated precession (Voigt et al., 2008). The OAE 2 interval consists of a $15 \mathrm{~m}$ thick succession of alternating limestones, marls and black shales. Black shale layers are typically $10-30 \mathrm{~cm}$ in thickness, but thicker layers (up to $2 \mathrm{~m}$ ) occur (Fig. 2). Black shales of the studied interval usually show a cyclic pattern with bedding couplets starting with laminated black shale that evolves into a marl and finally into a light-grey limestone. Four or five of these black shale couplets are part of a bundle that shows a decrease in black shale thickness and an increase in carbonate content up-section, illustrating strong orbital forcing of the Milankovitch periodicities. Our study focuses on a $1.1 \mathrm{~m}$ thick interval $(43.6-42.5 \mathrm{~m}$ core depth) that represents the lower part of one of the major packages of prominent black shale beds $(43.6-41.7 \mathrm{~m}$ core depth), the so-called Fischschiefer (after the occurrence of fish remains). The Fischschiefer is characterized by two distinct cycles of changes in the Ti concentrations derived from XRF core scanning (Fig. 2; Voigt et al., 2008). The thickness of these cycles is twice the thickness of regular precession couplets, where the cycles may represent two amalgamated precession cycles or one obliquity cycle. Changes of Ti concentrations reflect variations in the input of terrestrial material forced by orbital changes in humidity and run-off.

Benthic foraminifera were studied in 36 samples from the main Fischschiefer black shale layer of the Wunstorf core in a resolution of $2 \mathrm{~cm}$ and $5 \mathrm{~cm}$. After drying and weighing, samples were disaggregated using 3\% hydrogen peroxide solution for 30 minutes. Subsequently, samples were washed over a $63 \mu \mathrm{m}$ mesh and dry sieved into $63-125 \mu \mathrm{m}, 125-500 \mu \mathrm{m}$ and $>500 \mu \mathrm{m}$ fractions. Benthic foraminifera were studied in the 125-500 $\mu \mathrm{m}$ fraction. If necessary, samples were split and counts were recalculated for the whole sample. Benthic foraminiferal numbers were calculated as individuals per gram of dry sediment. Diversity is given in number of taxa per sample.

The elemental concentration of $\mathrm{S}, \mathrm{Si}, \mathrm{P}$ and $\mathrm{Al}$ of the investigated succession was measured using the XRF Core Scanner II located at the MARUM (Bremen University). Measurements were made over a $1 \mathrm{~cm}^{2}$ area every $2 \mathrm{~cm}$ for the low resolution and every $2 \mathrm{~mm}$ for the high resolution record, using a count time of 30 seconds (expressed as elemental counts over the measured area, e.g. S Area). Please note that XRF data are counted elemental concentrations and, therefore, not comparable to average shale values.

\section{Age and sedimentation rates of the study interval}

Applying spectral analysis of downhole gamma-ray data as well as XRF Ti elemental concentration, Voigt et al. (2008) were able to identify a frequency ratio diagnostic for the prominent Milankovitch frequencies of precession (21 ka) and short eccentricity $(100 \mathrm{ka})$. Using the dominant frequencies of precession and short eccentricity, a cyclostratigraphic age model was constructed for the black shale unit of the Wunstorf core, resulting in sedimentation rates of $3.0 \mathrm{~cm} \mathrm{ka}^{-1}$ for the studied Fischschiefer interval (Voigt et al., 2008). The studied interval (43.6-42.5 m core depth) therefore represents $\sim 37 \mathrm{ka}$ (approximately two precession cycles), resulting in a resolution of $\sim 670$ years and $\sim 1670$ years for our sample spacing of $2 \mathrm{~cm}$ and $5 \mathrm{~cm}$, respectively.

\section{RESULTS}

Low-resolution XRF elemental concentrations show pronounced increases in $\mathrm{Al}$ and $\mathrm{Si}$ associated with the black shale intervals (Fig. 2). Thereby, Si increases to values above 6000 counts whereas $\mathrm{Al}$ shows highest values in the lower part of the studied succession (up to 1400 counts). Sulphur elemental 


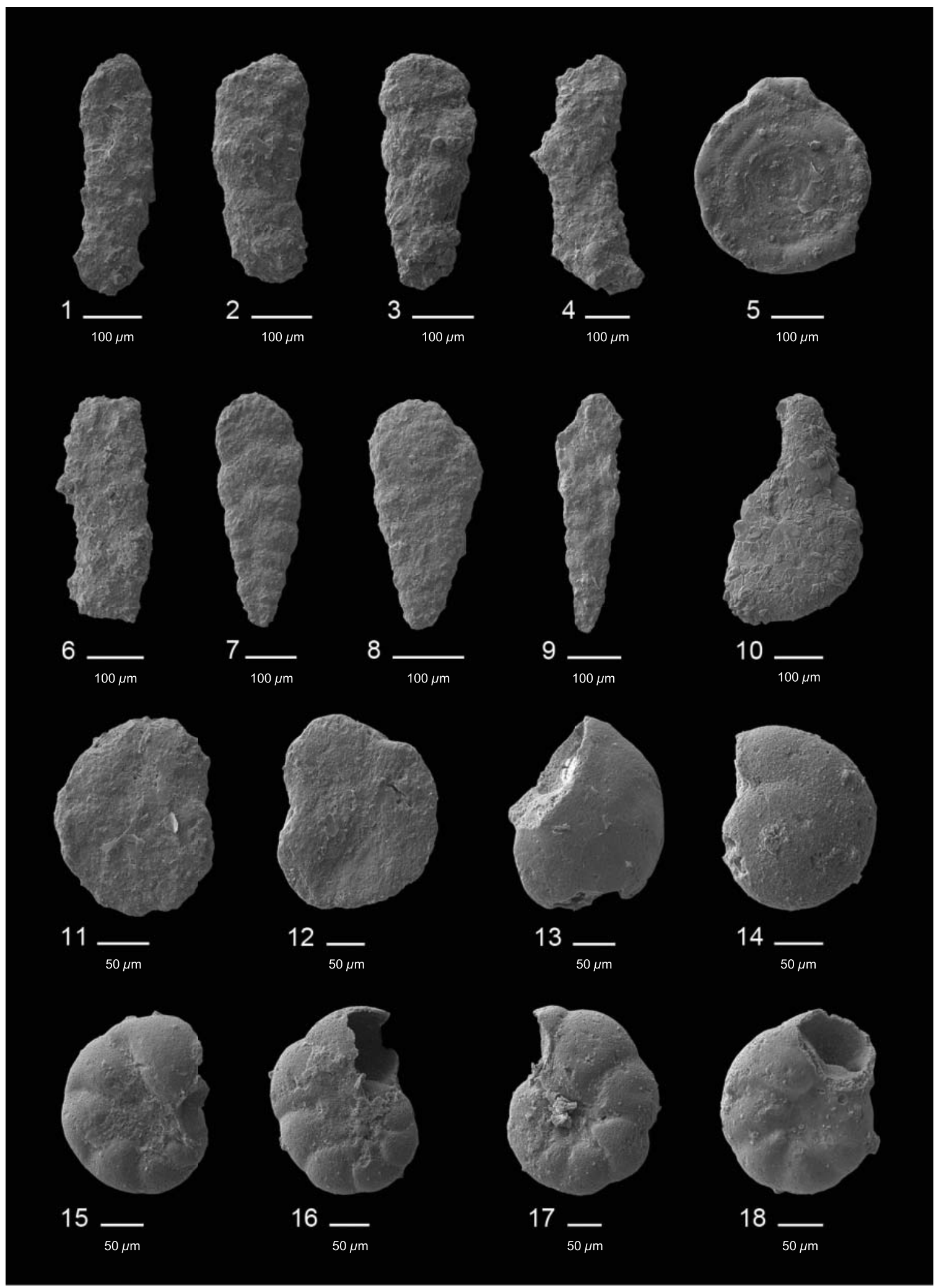

Explanation of Plate 1.

figs 1-18. Benthic foraminifera from the Fischschiefer at Wunstorf: 1, Ammobaculites sp.; 2, Bulbobaculites sp.; 3, Dorothia filiformis; 4, Rhabdammina sp.; 5, Ammodiscus cretaceous; 6, Rhizammina sp.; 7-8, Textularia obtusangula; 9, Textularia cf. praelonga; 10, Lagenammina sp.; 11-12, Haplophragmoides sp.; 13, Lenticulina rotulata; 14, Gyroidinoides parva; 15, 18, Lingulogavelinella globosa; 16, 17, Gavelinella dakotensis. 


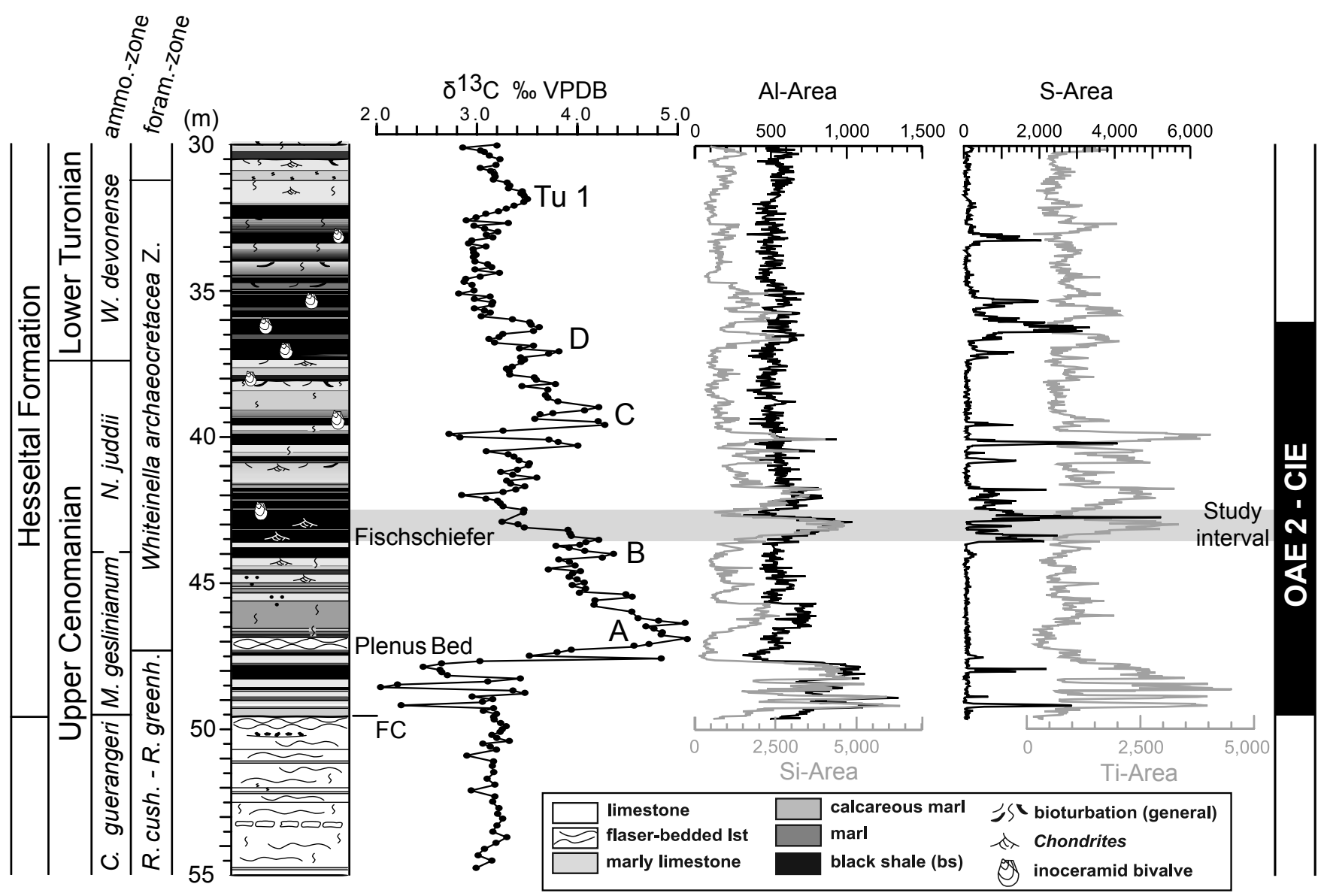

Fig. 2. Lithology, carbon isotope stratigraphy, biostratigraphy and low-resolution $(2 \mathrm{~cm}) \mathrm{XRF}$-aluminium, -silica, -sulphur and -titanium elemental concentrations of part of the Wunstorf core succession covering OAE 2 (after Voigt et al., 2008). Grey bar indicates study interval. CIE, carbon isotope excursion; FC, facies change; C., Calycoceras; M., Metoicoceras; N., Neocardioceras; W., Watinoceras; R. cush., Rotalipora cushmani; R. greenh., Rotalipora greenhornensis. Titanium elemental concentrations after Voigt et al. (2008).

concentration remains low within marls and limestones (values between 0 and 500 counts) but increases significantly within the black shale layers (usually values of 2000 to 6000 counts; Fig. 2).

The SEC show fluctuations between 1600 and 7500 counts for most of the succession of the high-resolution record (43.60$43.22 \mathrm{~m}$ and 42.86-42.50 m; Fig. 3). Maximum concentrations with values up to 12500 counts occur at $42.77 \mathrm{~m}$ and $42.73 \mathrm{~m}$. Between $43.20 \mathrm{~m}$ and $42.86 \mathrm{~m}$ SEC are characterized by two intervals of values close to zero. These intervals are from $43.18-43.10 \mathrm{~m}$ and from $43.00-42.92 \mathrm{~m}$, which are separated by slightly increased values of 2000 to 3000 counts (Fig. 3). Si/Al ratios for this interval are generally above 2 and are characterized by a significant increase to values of up to 6.8 between $43.00 \mathrm{~m}$ and $43.10 \mathrm{~m}$. Phosphorus elemental concentrations vary between -100 and 200 counts with highest values paralleling high $\mathrm{Si} / \mathrm{Al}$ ratios (Fig. 3).

Benthic foraminifera are barren for a large part of the studied core interval (below $43.31 \mathrm{~m}$ and above $42.88 \mathrm{~m}$; Fig. 4). The number of benthic foraminiferal individuals per gram of dried sediment (BFN) and diversity (number of counted taxa) increase during the two intervals of lower SEC, most pronounced during the upper one. But also below the lower low-SEC interval BFN and diversity increase rapidly from one sample to the other at
$43.31 \mathrm{~m}, 43.25 \mathrm{~m}$ and $43.23 \mathrm{~m}$. All three samples are located just above or within significant decreases in SEC (Fig. 4). While BFN are generally low, with maximum numbers of 7.5 individuals per gram, diversity is relatively high (up to 14 taxa) for a laminated black shale.

Main components of the benthic foraminiferal fauna are agglutinated taxa like Trochammina sp., Textularia (T. obtusangula and $T$. cf. praelonga), Rhizammina sp., Rhabdammina sp. and Dorothia filiformis among others (Fig. 5; Plate 1). The only calcareous taxa occurring in higher abundances $(>1 \%)$ is Lingulogavelinella globosa. While all of these taxa are abundant during the higher low-SEC interval, only textularids and Rhizammina sp. show higher abundances during the lower interval. Assemblages below that interval are dominated by Lingulogavelinella globosa, Rhabdammina sp. and textularids (Fig. 5). Ammodiscus cretaceous is the only species that occurs mainly outside of the low-SEC intervals.

\section{DISCUSSION}

Formation of the Fischschiefer black shale

The Fischschiefer black shale at Wunstorf has been suggested to correspond with high sea-level and orbitally forced weakening 


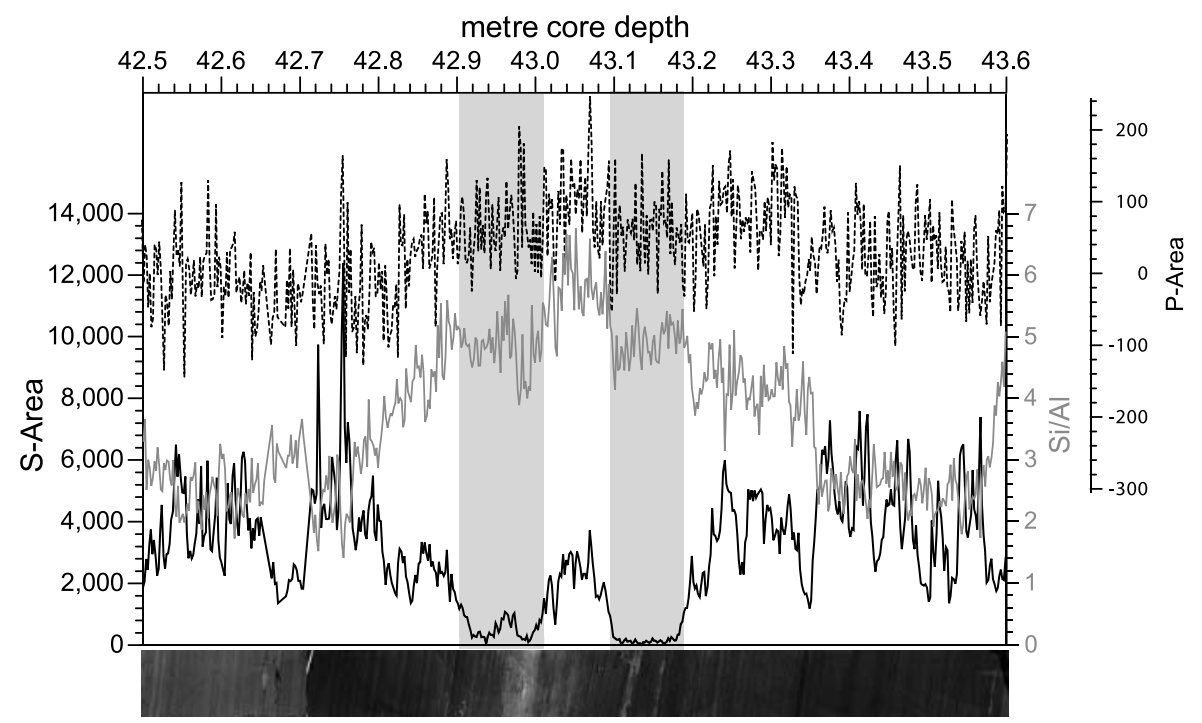

Fig. 3. High-resolution $(2 \mathrm{~mm}) \mathrm{XRF}$-sulphur and phosphorus elemental concentrations and $\mathrm{Si} / \mathrm{Al}$ ratio against core depth. Grey bars indicate intervals of low sulphur element concentrations, which are indicated by lighter lithology and less abundant lamination in the core pictures.

or even disappearance of shelf-break fronts that allowed the 2008). XRF elemental concentrations clearly indicate an spread of oceanic surface waters onto the shelf sea (Voigt et al., increase in detrital elements (Al, Ti; Fig. 2) during the
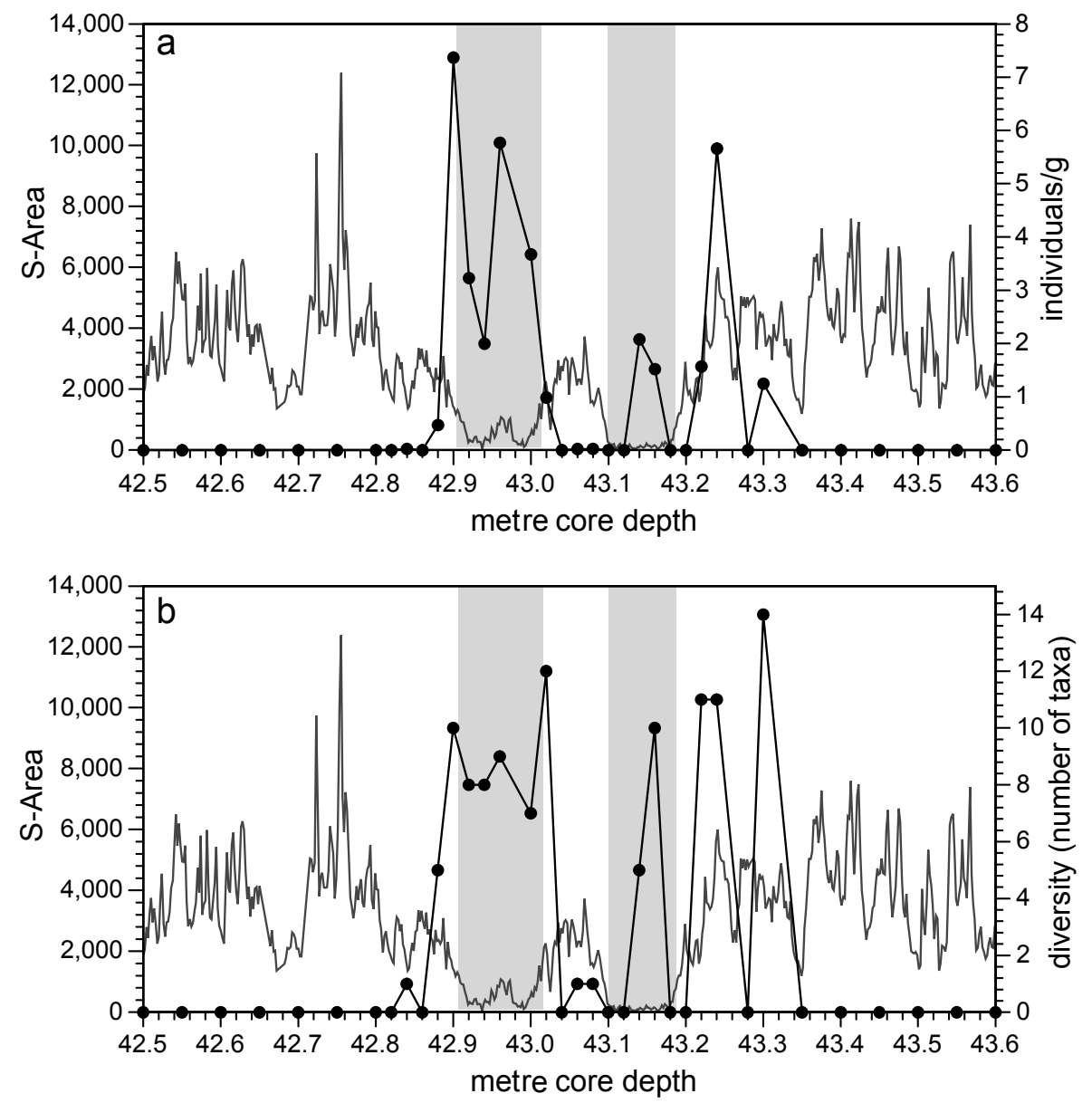

Fig. 4. Benthic foraminiferal assemblages and XRF-sulphur elemental concentrations of the studied interval against core depth: (a) benthic foraminiferal number as individuals per gram; (b) diversity as total number of taxa per sample. Grey bars indicate intervals of low sulphur element concentrations. 


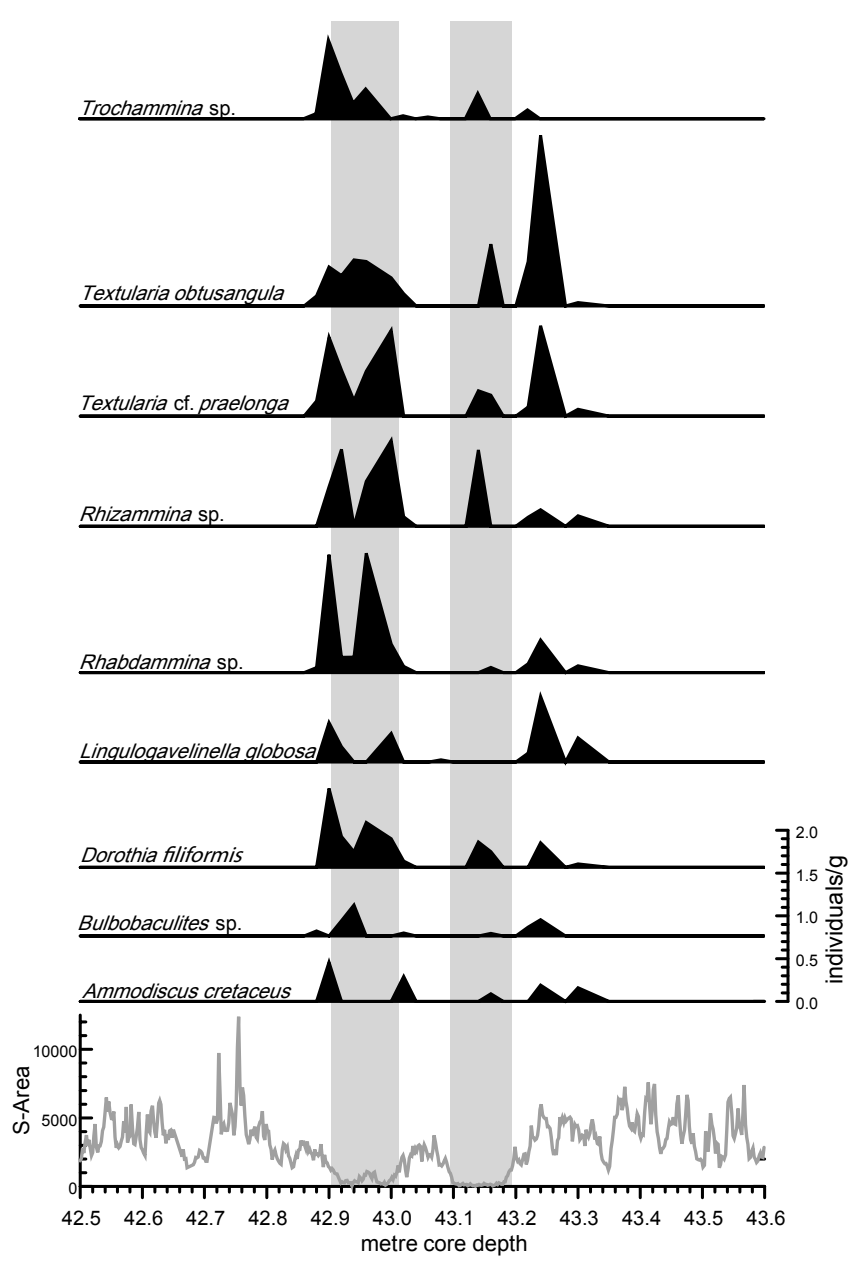

Fig. 5. Absolute abundance (individuals per gram) of benthic foraminiferal taxa and XRF-sulphur elemental concentrations of the studied interval against core depth. Shown are all taxa that count for more than $1 \%$ of the total assemblage and that occur in more than one sample. All at same scale. Grey bars indicate intervals of low sulphur element concentrations.

Fischschiefer deposition that represents two obliquity or amalgamated precession cycles (Voigt et al., 2008). This suggests an increase in the amount of terrigenous supply triggered by orbitally driven changes in humidity and/or runoff from the hinterland, leading to enhanced productivity and the establishment of an estuarine shelf circulation in the NW European shelf sea. This favoured black shale formation in the deeper parts of the shelf sea basins where bottom-water ventilation was probably diminished and oxygen was consumed by enhanced organic-matter flux to the seafloor (see also discussion in Voigt et al., 2008).

The proposed scenario for the formation of the Fischschiefer was, however, not a stable system but shows internal variability. Within the Fischschiefer succession itself, two intervals of lighter sediments can be distinguished that are also characterized by a significant decrease in SEC (Fig. 3).

\section{Characterization of black shale interruptions}

Black shales are generally deposited under oxygen-depleted conditions and, therefore, allow for the reconstruction of bottom-water and sediment redox conditions. Enrichment of redox-sensitive (e.g. Fe and $\mathrm{S}$ ) and sulfide-forming trace metals provide the opportunity to reconstruct the dynamics of biogeochemical element cycles and corresponding bottom-water redox conditions during the formation of black shales (e.g. Böttcher et al., 2006; Brumsack, 2006; Hetzel et al., 2009). Hydrogen sulfide formed by dissimilatory sulfate reduction transforms reactive iron into iron sulfides, mainly pyrite $\left(\mathrm{FeS}_{2}\right)$. Assuming that most of the sulphur occurring in the investigated Wunstorf black shales is captured as pyrite (Sageman \& Lyons, 2004; Takashima et al., 2011), SEC measured by XRF is used as an indicator of redox conditions and, therefore, oxygenation at the seafloor. Based on this assumption, two intervals of low SEC have been identified within the Fischschiefer interval (Fig. 3). The assumption that these intervals of low SEC reflect more oxygenated bottom-water conditions is supported by sedimentological observations, such as less abundant lamination or lighter colours of the sediment (see core picture in Fig. 3). Intervals with higher SEC are characterized by laminated intervals, interpreted herein as sedimentological evidence for anoxic bottom-water conditions.

Benthic foraminiferal assemblages show a significant reaction to these two intervals of proposed higher oxygen concentration. During both intervals, the formerly anoxic sediment (represented by high SEC, laminated dark sediment, and absence of benthic foraminifera) is characterized by increasing numbers of benthic foraminifera and higher diversity (Figs 4, 5). The presence of benthic foraminifera indicates a significant disturbance of the formerly anoxic seafloor. Increased oxygen concentrations allowed the benthic foraminifera to repopulate the seafloor for short time intervals. Outside the two low SEC intervals, benthic foraminifera declined and disappeared rapidly due to restoration of oxygen-depleted bottom-water conditions. The occurrence of benthic foraminifera in two intervals preceding the lower interval of low SEC indicates that oxygen increased for a short time. Both peaks in benthic foraminiferal abundances and diversity follow after an interval of low SEC and indicate very short periods of slightly higher oxygen concentration at the seafloor. It can be assumed that, in contrast to the two longer repopulation events up-section, these intervals were only brief snapshots of more oxygenated bottom waters that are recognized in the benthic foraminiferal assemblages but were not imprinted in the geochemical record. This would mean that palaeontological and geochemical signals are working on different time-scales during the deposition of these sediments, as proposed by former studies on mid-Cretaceous OAEs (Jiménez Berrocoso et al., 2008; Friedrich, 2010).

Benthic foraminiferal taxa that characterize the repopulation events at Wunstorf are typical taxa of organic-rich and oxygendepleted black shale environments. Textularids are a typical component of low-diversity OAE 2 black shale assemblages (e.g. Jarvis et al., 1988; Koutsoukos et al., 1990; Kuhnt \& Wiedmann, 1995; Hart, 1996; Paul et al., 1999). Elongated agglutinated foraminiferal taxa, such as Rhabdammina and Rhizammina, are described from oxygen-depleted sediments of different midCretaceous black shales including OAE 2 (e.g. Coccioni \& Galeotti, 1993; Kuhnt \& Wiedmann, 1995; Erbacher et al., 1998; Friedrich et al., 2003). In Italian sections, species such as Rhabdammina cyclindrica or Rhizammina indivisa are main 


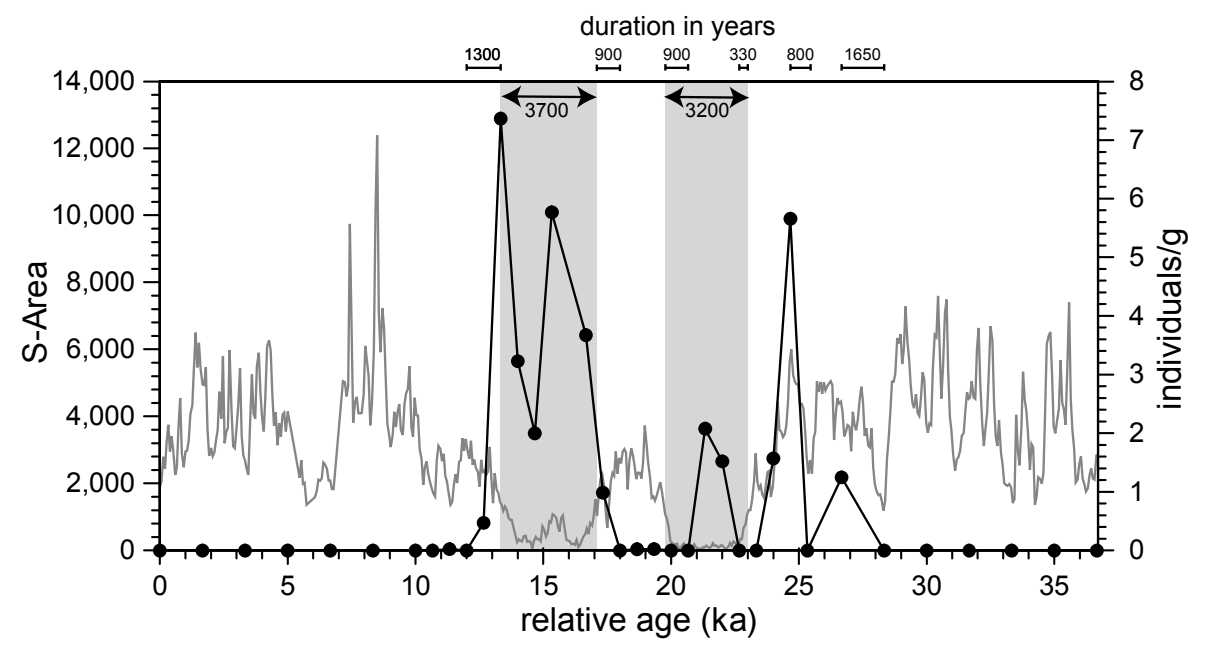

Fig. 6. Number of benthic foraminifera (individuals per gram) and XRF-sulphur elemental concentrations of the studied interval against relative age. Age model after Voigt et al. (2008). Duration of low sulphur element concentration intervals and leads and lacks between occurrence of benthic foraminifera and low XRF-sulphur element concentrations are given on top. Grey bars indicate intervals of low sulphur element concentrations.

components of a low diversity assemblage that occurred just below OAE 2 and are therefore interpreted as being tolerant to bottom-water anoxia (Coccioni et al., 1995). Thin-walled agglutinated taxa, such as Rhizammina, were also pioneer colonizers of sediments just above OAE 2 black shales barren in benthic foraminifera from the abyssal North Atlantic (Kuhnt, 1992). Two agglutinated taxa that also characterize the studied succession, Trochammina sp. and Dorothia filiformis, are described from Cretaceous sediments deposited under low-oxygen conditions (e.g. Nyong \& Ramanathan, 1985; Koutsoukos et al., 1990; Tronchetti \& Grosheny, 1991). From the Vocontian Basin (SE France), a fauna dominated by Trochammina is described from Aptian and Albian black shales (Erbacher et al., 1998; Friedrich et al., 2003). The genus Dorothia is generally suggested to be an indicator of meso- to eutrophic bottom-water conditions (e.g. Koutsoukos \& Hart, 1990; Coccioni \& Galeotti, 1993; Friedrich et al., 2003) and is common also in other black shale intervals at Wunstorf (Kuhnt \& Wiedmann, 1995). The only calcareous species, Lingulogavelinella globosa, occurs in a low-diversity assemblage with only three calcareous taxa left during OAE 2 in a borehole section in SE Poland and, therefore, suggests adaptation to low-oxygen conditions (Peryt \& Wyrwicka, 1991), an interpretation that is supported by other studies (e.g. Jarvis et al., 1988; Koutsoukos et al., 1990; Hart, 1996; Paul et al., 1999).

\section{Timing of repopulation events}

The available orbital time-scale for the Wunstorf core (Voigt et al., 2008) allows not only for reconstruction of the duration of single repopulation events but also for a detailed reconstruction of leads and lags between bottom-water oxygenation (as indicated by SEC) and occurrence of benthic foraminifera. Using the age model of Voigt et al. (2008), durations of the intervals with low SEC are $3.2 \mathrm{ka}$ and $3.7 \mathrm{ka}$ (Fig. 6). Given our $2 \mathrm{~cm}$ sampling resolution around these intervals (resulting in a sample spacing of 660 years), the observed repopulation events associated with these intervals are slightly shorter for the lower interval and slightly longer for the higher interval (Fig. 6). For the lower interval of low SEC (43.18-43.1 m), benthic foraminifera lag low SEC by 330 years and lead increasing SEC by 900 years. This results in a time span of approximately $2 \mathrm{ka}$ for the lower repopulation event. For the higher interval, benthic foraminiferal abundances lead the decrease by 900 years, while lagging the increase in SEC by 1300 years, which accounts for a significantly longer time span of approximately $6 \mathrm{ka}$ for this repopulation event. All calculated durations are maximum estimates based on the 660-year sample spacing. The observed short-term occurrences of benthic foraminifera before the lower interval of low SEC lag distinct decreases in SEC by 1650 years and 800 years, respectively (Fig. 6), possibly indicating different reaction times of the palaeontological and geochemical signals (see discussion above). These estimates, however, are biased by the higher sample spacing of $5 \mathrm{~cm}$ in this interval, resulting in a sample spacing of $1.66 \mathrm{ka}$.

\section{Comparison with other repopulation events}

Benthic foraminiferal repopulation events during OAE 2 have been described from the Western Interior Seaway (e.g. Eicher \& Worstell, 1970; Eicher \& Diner, 1985; Leckie, 1985; Keller et al., 2004), the tropical Atlantic Ocean (Friedrich et al., 2006) and Tarfaya (southern Morocco; Kuhnt et al., 2005), but none of these studies allows a reliable estimate of the duration of the repopulation events due to either low sampling resolution, lack of tuned age models, or both. If the estimated sedimentation rates for ODP Sites 1258, 1260 and 1261 at Demerara Rise (western tropical North Atlantic; Erbacher et al., 2005) are used to calculate the duration of the observed repopulation events in the lower third of OAE 2 (Friedrich et al., 2006), a duration of approximately 60-80 ka can be shown. Low sampling resolution and the pronounced, open-ocean oxygen minimum zone at Demerara Rise (Erbacher et al., 2004, 2005; Friedrich et al., 2006, 2008b), however, hinder a reliable comparison with the shelf-sea setting represented by the Wunstorf core.

A comparable study of benthic foraminiferal repopulation events has been done on the early Albian OAE 1b. The reconstructed duration of $2 \mathrm{ka}$ and $6 \mathrm{ka}$ for repopulation events 
in the Wunstorf core is, however, slightly longer. During OAE $1 \mathrm{~b}$, a total of eight cyclic repopulation events were described with an estimated duration of $\sim 500$ to 1250 years (Friedrich et al., 2005).

If compared to geologically younger oxygen-depleted sediments, the Mediterranean sapropels, the estimated duration of repopulation events during OAE 2 at Wunstorf is also slightly longer. Benthic foraminiferal repopulation events occurred repeatedly in Quaternary sapropels of the Eastern Mediterranean Sea and lasted up to 300 years for sapropel S1 and 300-1600 years for sapropels S5 and S6 (sapropel S1: Rohling et al., 1997; Casford et al., 2003; Kuhnt et al., 2007; sapropels S5 and S6: Casford et al., 2003; Schmiedl et al., 2003). This somewhat shorter duration might be related to the overall shorter duration of Quaternary sapropels (3-6 ka; Rohling et al., 1997; Casford et al., 2003; Schmiedl et al., 2010) compared to OAE 2 (430-600 ka; Sageman et al., 2006; Voigt et al., 2008).

Given the relatively short response time of a somehow diverse benthic foraminiferal fauna to repopulate the formerly anoxic bottom-water environments at Wunstorf (several hundreds of years), a nearby refuge for these species has to be inferred. For Quaternary sapropels, Casford et al. (2003) showed that benthic foraminifera are able to repopulate the deeper, formerly anoxic, eastern Mediterranean Basin within $<50$ years. Thereby, benthic foraminifera invaded the deeper basin from more oxygenated locations like shallower shelf waters or locations that are under the influence of at least sporadic oxygenation around the eastern Mediterranean Sea (e.g. Casford et al., 2003). An invasion of benthic foraminifera from shallower, more oxygenated environments is also a likely mechanism to explain the short response time of our observed repopulation events during OAE 2. Such environments occur in the shallower parts of the Lower Saxony Basin and the Münsterland Cretaceous Basin, where the OAE 2 interval lacks black shale sedimentation (e.g. Hilbrecht \& Dahmer, 1994; Voigt et al., 2006). Similarly, all sections where benthic foraminiferal repopulation events have been described during OAEs $1 \mathrm{~b}$ and 2 are close to shallow shelf sea areas around the Atlantic Ocean (e.g. Eicher \& Worstell, 1970; Erbacher et al., 1999; Holbourn et al., 2001a; Friedrich et al., 2005, 2006). These shallow shelf seas and/or deeper settings below the oxygen minimum zone in case of the tropical North Atlantic could have served as source areas for the repopulation of former anoxic seafloor environments.

\section{Trigger mechanisms of repopulation events and palaeoceanographic implications}

Despite having different durations and ages, repopulation events of OAE $1 \mathrm{~b}$ and the Mediterranean sapropels show remarkable similarities in terms of palaeoceanographic and palaeoclimatic trigger mechanisms. The repopulation events described for OAE $1 \mathrm{~b}$ are proposed to show ventilation of intermediate to deep waters due to short-term cooling and reduced humidity in the source areas of water-mass formation under the monsoonal climate system of the mid-Cretaceous low latitudes (e.g. Erbacher et al., 2001; Herrle et al., 2003a, b; Friedrich et al., 2005). Thereby, these authors postulate an increase in lowlatitude deep-water formation via enhanced evaporation, leading to the observed bottom-water oxygenation as indicated by the occurrence of benthic foraminifera. During formation of Quaternary sapropels S1, S5 and S6, the generally warm and humid climate conditions are interrupted by short intervals of cooling that are proposed to initiate deep-water formation and re-ventilation of deep-sea ecosystems (Rohling et al., 1997; Myers \& Rohling, 2000; Casford et al., 2003; Schmiedl et al., 2003, 2010; Kuhnt et al., 2007).

Temperature estimates for the Wunstorf core are not available. However, there are remarkable similarities between the studied succession at Wunstorf and the sections in the Vocontian Basin (OAE 1b) and the Mediterranean Sea. All three represent marginal sea settings that are characterized by the formation of organic-rich sediments under increasingly humid conditions (at Wunstorf indicated by the increased supply of detrital elements during Fischschiefer formation). In all sections it is proposed that increased fresh-water supply and subsequent stratification of the water column caused decreased deep-water formation and thus low $\mathrm{O}_{2}$ concentrations at the seafloor (e.g. Rohling et al., 1997; Herrle et al., 2003a; this study). These similarities and the co-occurrence of cooling and repopulation events during OAE $1 \mathrm{~b}$ and the Quaternary sapropels might suggest a similar cause-reaction relationship for the observed repopulation events in the Wunstorf area. Increased formation of local bottom-water masses on the NW European shelf sea could have led to short-term ventilation of the deeper parts of the Lower Saxony Basin and, therefore, enabled benthic foraminifera to repopulate the formerly anoxic seafloor. Thereby, $\mathrm{Si} / \mathrm{Al}$ ratios and $\mathrm{P}$ elemental concentrations remain high even during the repopulation events (Fig. 3). Assuming $\mathrm{Si} / \mathrm{Al}$ reflect biogenic production of silica (e.g. Wedepohl, 1971; Dickson et al., 2010) and using $\mathrm{P}$ as productivity proxy (e.g. Föllmi, 1996), these high values indicate a constantly enhanced productivity. This suggests seafloor ventilation rather than reduced organic matter supply as the main trigger for the observed repopulation events.

Overall, the repeated occurrence of benthic foraminiferal repopulation events in Cretaceous OAEs makes a strong argument for severe short-term perturbations of the general palaeoclimatic and palaeoceanographic trigger mechanisms responsible for bottom-water anoxia in open-ocean and shelf sea environments.

\section{ACKNOWLEGEMENTS}

We thank W. Schiller (Frankfurt) for technical support, J. Erbacher (Hannover) and J. Mutterlose (Bochum) for access to the core material, and A. Wülbers for sampling support. The constructive review of A. Jiménez Berrocoso is gratefully acknowledged. This work was funded by the Deutsche Forschungsgemeinschaft (Emmy Noether research grant Fr 2544/2-1 to OF, TK and MK and grant Vo $687 / 7$ to SV).

\section{Manuscript received 29 November 2011 Manuscript accepted 14 May 2011}

Scientific editing by Tom Dunkley Jones

\section{REFERENCES}

Arthur, M.A., Dean, W.E. \& Pratt, L.M. 1988. Geochemical and climatic effects of increased marine organic carbon burial at the Cenomanian/Turonian boundary. Nature, 335: 714-717. 
Bornemann, A., Norris, R.D., Friedrich, O. et al. 2008. Isotopic evidence for glaciation during the Cretaceous supergreenhouse. Science, 319: 189-192.

Böttcher, M., Hetzel, A., Brumsack, H. \& Schipper, A. 2006. SulfurIron-Carbon Geochemistry in Sediments of the Demerara Rise. ODP Scientific Results, 207: 1-23.

Brumsack, H. 2006. The trace metal content of recent organic carbonrich sediments: Implications for Cretaceous black shale formation. Palaeogeography, Palaeoclimatology, Palaeoecology, 232: 344-361.

Casford, J.S.L., Rohling, E.J., Abu-Zied, R.H. et al. 2003. A dynamic concept for eastern Mediterranean circulation and oxygenation during sapropel formation. Palaeogeography, Palaeoclimatology, Palaeoecology, 190: 103-119.

Coccioni, R. \& Galeotti, S. 1993. Orbitally induced cycles in benthic foraminiferal morphogroups and trophic structure distribution patterns from the Late Albian 'Amadeus Segment' (Central Italy). Journal of Micropaleontology, 12: 227-239.

Coccioni, R., Galeotti, S. \& Gravili, M. 1995. Latest Albian-earliest Turonian deep-water agglutinated foraminifera in the Bottachione section (Gubbio, Italy) - Biostratigraphy and paleoecological implications. Revista Espanola de Paleontologia, Volumen Homenaje al Dr. Guillermo Colom: 135-152.

Dickson, A.J., Leng, M.J., Maslin, M.A. \& Röhl, U. 2010. Oceanic, atmospheric and ice-sheet forcing of South East Atlantic Ocean productivity and South African monsoon intensity during MIS-12 to 10. Quaternary Science Reviews, 29: 3936-3947.

Eicher, D. \& Diner, R. 1985. Foraminifera as indicators of water mass in the Cretaceous Greenhorn Sea, Western Interior. Society of Economic Paleontologists and Mineralogists Field Trip Guidebook, 4: 60-71.

Eicher, D.L. \& Worstell, P. 1970. Cenomanian and Turonian foraminifera from the Great Plains, United States. Micropaleontology, 16: 269-324.

Erbacher, J., Friedrich, O., Wilson, P.A., Birch, H. \& Mutterlose, J. 2005. Stable organic carbon isotope stratigraphy across Oceanic Anoxic Event 2 of Demerara Rise, western tropical Atlantic. Geochemistry, Geophysics, Geosystems, 6: Q06010, DOI: 10.1029/ 2004GC000850.

Erbacher, J., Gerth, W., Schmiedl, G. \& Hemleben, C. 1998. Benthic foraminiferal assemblages of Late Aptian-Early Albian black shale intervals in the Vocontian Basin, SE France. Cretaceous Research, 19: 805-826.

Erbacher, J., Hemleben, C., Huber, B.T. \& Markey, M. 1999. Correlating environmental changes during Early Albian oceanic anoxic event 1B using benthic foraminiferal paleoecology. Marine Micropaleontology, 38: 7-28.

Erbacher, J., Huber, B.T., Norris, R.D. \& Markey, M. 2001. Increased thermohaline stratification as a possible cause for an ocean anoxic event in the Cretaceous period. Nature, 409: 325-327.

Erbacher, J., Mosher, D. \& Malone, M. Shipboard Scientific Party. 2004. Drilling probes past carbon cycle perturbations on the Demerara Rise. EOS, 85: 57-68.

Föllmi, K.B. 1996. The phosphorus cycle, phosphogenesis and marine phosphate-rich deposits. Earth-Science Reviews, 40: 55-124.

Forster, A., Schouten, S., Moriya, K., Wilson, P.A. \& Sinninghe Damsté, J.S. 2007. Tropical warming and intermettent cooling during the Cenomanian/Turonian oceanic anoxic event 2: Sea surface temperature records from the equatorial Atlantic. Paleoceanography, 22: DOI: $10.1029 / 2006$ PA001349.

Friedrich, O. 2010. Benthic foraminifera and their role to decipher paleoenvironment during mid-Cretaceous Oceanic Anoxic Events the 'anoxic benthic foraminifera' paradox. Revue de Micropaleontologie, 53: 175-192.

Friedrich, O., Erbacher, J., Moriya, K., Wilson, P.A. \& Kuhnert, H. 2008a. Warm saline intermediate waters in the Cretaceous tropical Atlantic Ocean. Nature Geoscience, 1: 453-457.

Friedrich, O., Erbacher, J. \& Mutterlose, J. 2006. Paleoenvironmental changes across the Cenomanian/Turonian Boundary Event (Oceanic Anoxic Event 2) as indicated by benthic foraminifera from the Demerara Rise (ODP Leg 207). Revue de Micropaleontologie, 49: $121-139$.
Friedrich, O., Nishi, H., Pross, J., Schmiedl, G. \& Hemleben, C. 2005. Millennial- to centennial-scale interruptions of the Oceanic Anoxic Event 1b (Early Albian, mid-Cretaceous) inferred from benthic foraminiferal repopulation events. Palaios, 20: 64-77.

Friedrich, O., Norris, R.D., Bornemann, A. et al. 2008b. Cyclic changes in Turonain to Coniacian planktic foraminferal assemblages from the tropical Atlantic Ocean. Marine Micropaleontology, 68: 299-313.

Friedrich, O., Reichelt, K., Herrle, J.O., Lehmann, J., Pross, J. \& Hemleben, C. 2003. Formation of the Late Aptian Niveau Fallot black shales in the Vocontian Basin (SE France): evidence from foraminifera, palynomorphs, and stable isotopes. Marine Micropaleontology, 49: 65-85.

Gebhardt, H., Friedrich, O., Schenk, B., Fox, L., Hart, M. \& Wagreich, M. 2010. Paleoceanographic changes at the northern Tethyan margin during the Cenomanian-Turonian oceanic anoxic event (OAE-2). Marine Micropaleontology, 77: 25-45.

Hardas, P. \& Mutterlose, J. 2007. Calcareous nannofossil assemblages of Oceanic Anoxic Event 2 in the equatorial Atlantic: Evidence of an eutrophication event. Marine Micropaleontology, 66: 52-69.

Hart, M. 1996. Recovery of the food chain after the Late Cenomanian extinction event. In: Hart, M.B. (Ed.), Biotic Recovery From Mass Extinction Events. Geological Society, London, Special Publications, 102: $265-277$.

Hasegawa, T. 1997. Cenomanian-Turonian carbon isotope events recorded in terrestrial organic matter from northern Japan. Palaeogeography, Palaeoclimatology, Palaeoecology, 130: 251-273.

Herrle, J.O., Pross, J., Friedrich, O. \& Hemleben, C. 2003a. Short-term environmental changes in the Cretaceous Tethyan Ocean: micropaleontological evidence from the Early Albian Oceanic Anoxic Event 1b. Terra Nova, 15: 14-19.

Herrle, J.O., Pross, J., Friedrich, O., Kößler, P. \& Hemleben, C. 2003b. Forcing mechanisms for mid-Cretaceous black shale formation: evidence from the Upper Aptian and Lower Albian of the Vocontian Basin (SE France). Palaeogeography, Palaeoclimatology, Palaeoecology, 190: 399-426.

Hetzel, A., Böttcher, M., Wortmann, U. \& Brumsack, H. 2009. Paleoredox conditions during OAE 2 reflected in Demerara Rise sediment geochemistry (ODP Leg 207). Palaeogeography, Palaeoclimatology, Palaeoecology, 273: 302-328.

Hilbrecht, H. \& Dahmer, D. 1994. Sediment dynamics during the Cenomanian-Turonian (Cretaceous) Oceanic Anoxic Event in Northwestern Germany. Facies, 30: 63-84.

Holbourn, A. \& Kuhnt, W. 2002. Cenomanian-Turonian paleoceanographic change on the Kerguelen Plateau: a comparison with Northern Hemisphere records. Cretaceous Research, 23: 333-349.

Holbourn, A., Kuhnt, W. \& Erbacher, J. 2001a. Benthic foraminifers from Lower Albian black shales (Site 1049, ODP Leg 171): Evidence for a non 'uniformitarian' record. Journal of Foraminiferal Research, 31: $60-74$.

Holbourn, A., Kuhnt, W. \& Soeding, E. 2001b. Atlantic paleobathymetry, paleoproductivity and paleocirculation in the late Albian: the benthic foraminiferal record. Palaeogeography, Palaeoclimatology, Palaeoecology, 170: 171-196.

Huber, B.T., Norris, R.D. \& MacLeod, K.G. 2002. Deep-sea paleotemperature record of extreme warmth during the Cretaceous. Geology, 30: $123-126$.

Jarvis, I., Carson, G., Cooper, K. et al. 1988. Microfossil assemblages and the Cenomanian-Turonian (Late Cretaceous) oceanic anoxic event. Cretaceous Research, 9: 3-103.

Jiménez Berrocoso, A., MacLeod, K.G., Calvert, S.E. \& Elorza, J. 2008. Bottom water anoxia, inoceramid colonization, and bentho-pelagic coupling during black shale deposition on Demerara Rise (Late Cretaceous western tropical North Atlantic). Paleoceanography, 23, DOI: 10.1029/2007PA001545.

Keller, G., Berner, Z., Adatte, T. \& Stueben, D. 2004. CenomanianTuronian and $\mathrm{d}^{13} \mathrm{C}$, and $\mathrm{d}^{18} \mathrm{O}$, sea level and salinity variations at Pueblo, Colorado. Palaeogeography, Palaeoclimatology, Palaeoecology, 211: 19-43.

Kolonic, S., Wagner, T., Forster, A. et al. 2005. Black shale deposition on the northwest African Shelf during the Cenomanian/Turonian 
oceanic anoxic event: Climate coupling and global organic carbon burial. Paleoceanography, 20: DOI: 10.1029/2003PA000950.

Koutsoukos, E. \& Hart, M. 1990. Cretaceous foraminiferal morphogroup distribution patterns, paleocommunities and trophic structures: a case study from the Sergipe Basin, Brazil. Transactions of the Royal Society of Edinburgh, Earth Sciences, 81: 221-246.

Koutsoukos, E.A.M., Leary, P.M. \& Hart, M.B. 1990. Latest Cenomanian-earliest Turonian low-oxygen tolerant benthonic foraminifera: a case study from the Sergipe Basin (N.E. Brazil) and the western Anglo-Paris Basin (southern England). Palaeogeography, Palaeoclimatology, Palaeoecology, 77: 145-177.

Kuhnt, T., Schmiedl, G., Ehrmann, W., Hamann, Y. \& Hemleben, C. 2007. Deep-sea ecosystem variability of the Aegean Sea during the past $22 \mathrm{kyr}$ as revealed by benthic foraminifera. Marine Micropaleontology, 64: 141-162.

Kuhnt, W. 1992. Abyssal recolonization by benthic foraminifera after the Cenomanian/Turonian boundary anoxic event in the North Atlantic. Marine Micropaleontology, 19: 257-274.

Kuhnt, W., Luderer, F., Nederbragt, A.J., Thurow, J. \& Wagner, T. 2005. Orbital-scale record of the late Cenomanian-Turonian oceanic anoxic event (OAE-2) in the Tarfaya Basin (Morocco). International Journal of Earth Sciences, 94: 147-159.

Kuhnt, W. \& Wiedmann, J. 1995. Cenomanian-Turonian source rocks: Paleobiogeographic and paleoenvironmental aspects. American Association of Petroleum Geologists, Studies in Geology, 40: 213-232.

Kuypers, M.M.M., Pancost, R.D., Nijenhuis, I.A. \& Sinninghe Damsté, J.S. 2002. Enhanced productivity led to increased organic carbon burial in the euxinic North Atlantic basin during the late Cenomanian oceanic anoxic event. Paleoceanography, 17: DOI: 10.1029/ 2000PA000569.

Leckie, R. 1985. Foraminifera of the Cenomanian-Turonian boundary interval, Greenhorn Formation, Rock Canyon Anticline, Pueblo, Colorado. Society of Economic Paleontologists and Mineralogists, Field Trip Guidebook, 4: 139-155.

Leckie, R.M., Bralower, T.J. \& Cashman, R. 2002. Oceanic anoxic events and plankton evolution: Biotic response to tectonic forcing during the mid-Cretaceous. Paleoceanography, 17: DOI: 10.1029/ 2001PA000623.

Leckie, R.M., Yuretich, R.F., West, O.L.O., Finkelstein, D. \& Schmidt, M. 1998. Paleoceanography of the southwestern Western Interior Sea during the time of the Cenomanian-Turonian boundary (Late Cretaceous). Society of Economic Paleontologists and Mineralogists, Concepts in Sedimentology and Paleontology, 6: 101-126.

Moriya, K., Wilson, P.A., Friedrich, O., Erbacher, J. \& Kawahata, H. 2007. Testing for ice sheets during the mid-Cretaceous greenhouse using glassy foraminiferal calcite from the mid-Cenomanian tropics on Demerara Rise. Geology, 35: 615-618.

Myers, P. \& Rohling, E. 2000. Modeling a 200-yr interruption of the Holocene sapropel S1. Quaternary Research, 53: 98-104.

Norris, R.D., Bice, K.L., Magno, E.A. \& Wilson, P.A. 2002. Jiggling the tropical thermostat in the Cretaceous hothouse. Geology, 30: 299-302.

Nyong, E.E. \& Ramanathan, R. 1985. A record of oxygen-deficient paleoenvironments in the Cretaceous of the Calabar Flank, SE Nigeria. Journal of African Earth Sciences, 3: 455-460.

Pancost, R.D., Crawford, N., Magness, S., Turner, A., Jenkyns, H.C. \& Maxwell, J.R. 2004. Further evidence for the developement of photiczone euxinic conditions during Mesozoic oceanic anoxic events. Journal of the Geological Society, London, 161: 353-364.

Paul, C., Lamolda, M., Mitchell, S., Vaziri, M., Gorostidi, A. \& Marshall, J. 1999. The Cenomanian-Turonian boundary at Eastbourne (Sussex, UK): a proposed European reference section. Palaeogeography, Palaeoclimatology, Palaeoecology, 150: 83-121.

Peryt, D. \& Wyrwicka, K. 1991. The Cenomanian-Turonian oceanic anoxic event in SE Poland. Cretaceous Research, 12: 65-80.
Pratt, L.M. \& Threlkeld, C.N. 1984. Stratigraphic significance of ${ }^{13} \mathrm{C} /{ }^{12} \mathrm{C}$ ratios in mid-Cretaceous rocks of the Western Interior, U.S.A. Canadian Society of Petroleum Geologists, Memoir, 9: 305312

Rohling, E., Jorissen, F. \& De Stigter, H. 1997. 200 year interruption of Holocene sapropel formation in the Adriatic Sea. Journal of Micropalaeontology, 16: 97-108.

Sageman, B.B. \& Lyons, T.W. 2004. Geochemistry of fine-grained sediments and sedimentary rocks. Treatise on Geochemistry, 7: 115158.

Sageman, B.B., Meyers, S.R. \& Arthur, M.A. 2006. Orbital time scale and new C-isotope record for Cenomanian-Turonian boundary stratotype. Geology, 34: 125-128.

Schlanger, S.O. \& Jenkyns, H.C. 1976. Cretaceous Oceanic Anoxic Events: Causes and consequences. Geologie en Mijnbouw, 55: 179-184.

Schmiedl, G., Kuhnt, T., Ehrmann, W. et al. 2010. Climatic forcing of eastern Mediterranean deep-water formation and benthic ecosystems during the past 22000 years. Quaternary Science Reviews, 29: 30063020.

Schmiedl, G., Mitschele, A., Beck, S. et al. 2003. Benthic foraminiferal record of ecosystem variability in the eastern Mediterranean Sea during times of sapropel S5 and S6 deposition. Palaeogeography, Palaeoclimatology, Palaeoecology, 190: 139-164.

Scholle, P.A. \& Arthur, M.A. 1980. Carbon isotope fluctuations in Cretaceous pelagic limestones: Potential stratigraphic and petroleum exploration tool. Bulletin of the American Association of Petroleum Geologists, 64: 67-87.

Sinninghe Damstè, J.S., van Bentum, E.C., Reichart, G.-J., Pross, J. \& Schouten, S. 2010. A CO2 decrease-driven cooling and increased latitudinal temperature gradient during the mid-Cretaceous Oceanic Anoxic Event 2. Earth and Planetary Science Letters, 293: 97-103.

Surlyk, F., Dons, T., Clausen, C.K. \& Higham, J. 2003. Upper Cretaceous. In: Evans, D., Graham, C., Armour, A. \& Bathurst, P. (Eds), The Millennium Atlas: Petroleum Geology of the Central and Northern North Sea. Geological Society of London, London, 213-233.

Takashima, R., Nishi, H. \& Yamanaka, T. etal. 2011. Prevailing oxic environments in the Pacific Ocean during the mid-Cretaceous Oceanic Anoxic Event 2. Nature Communications, 2:234, DOI: 10.1038/ ncomms 1233 .

Tronchetti, G. \& Grosheny, D. 1991. Les assemblages de Foraminifères benthiques au passage Cénomanien-Turonien à Vergons, S-E France. Geobios, 24: 13-31.

Voigt, S., Erbacher, J., Mutterlose, J. et al. 2008. The Cenomanian Turonian of the Wunstorf section (North Germany): global stratigraphic reference section and new orbital time scale for Oceanic Anoxic Event 2. Newsletters on Stratigraphy, 43: 65-89.

Voigt, S., Gale, A.S. \& Voigt, T. 2006. Sea-level change, carbon cycling and palaeoclimate during the Late Cenomanian of northwest Europe; an integrated palaeoenvironmental analysis. Cretaceous Research, 27: 836-858.

Wedepohl, K.H. 1971. Environmental influences on the chemical composition of shales and clays. In: Ahrens, L.H., Press, F., Runcorn, S.K. \& Urey, H.C. (Eds), Physics and Chemistry of the Earth 8. Pergamon, Oxford, 305-333.

West, O.L.O., Leckie, R.M. \& Schmidt, M. 1998. Foraminiferal paleoecology and paleoceanography of the Greenhorn Cycle along the southwestern margin of the Western Interior sea. SEPM Concepts in Sedimentology and Paleontology, 6: 79-99.

Wilmsen, M. 2003. Sequence stratigraphy and palaeoceanography of the Cenomanian Stage in northern Germany. Cretaceous Research, 24: $525-568$.

Wilson, P.A., Norris, R.D. \& Cooper, M.J. 2002. Testing the Cretaceous greenhouse hypothesis using glassy foraminiferal calcite from the core of the Turonian tropics on Demerara Rise. Geology, 30: 607-610. 